\title{
Effect of Planting Time on Canopy Structure and Biomass Production in Some Soybean Genotypes
}

\author{
M. K. UdDIN ${ }^{1 *}$, M. K. HASAN ${ }^{2}$ AND A. K. M. A. ALAM ${ }^{3}$ \\ ${ }^{1}$ Entomology Division, Bangladesh Agricultural Research Institute, Joydebpur, Gazipur, Bangladesh \\ ${ }^{2}$ On Farm Research Division, Bangladesh Agricultural Research Institute, Joydebpur, Gazipur, Bangladesh \\ ${ }^{3}$ School of Agriculture and Rural Development, Bangladesh Open University, Gazipur, Bangladesh
}

\begin{abstract}
A field experiment was conducted in the Field Laboratory of the Department of Crop Botany, BAU, Mymensingh during November 2003 to May 2004 to assess the effect of planting time (November and December) on some morphological structure, and root \& shoot biomass production in four soybean genotypes (GPB-1, GPB-2, AGS-332 and AGS-11-35). The plant height, stem base diameter, seed dry weight plant ${ }^{-1}$ were significantly greater in the late planting crops (December) but number of branches plant $t^{-1}$, number of leaves plant ${ }^{-1}$, leaves dry weight plant ${ }^{-1}$, shoots dry weight plant ${ }^{-1}$, roots dry weight plant ${ }^{-1}$, total dry matter plant ${ }^{-1}$ were also significantly greater in November planting. Highest plant height, branches plant ${ }^{-1}$ and leaves plant ${ }^{-1}$, shoot dry weight plant ${ }^{-1}$ and total dry matter were found in GPB-2 genotype.
\end{abstract}

Key words: Early and late planting, shoot and root mass, Glycine max.

\section{INTRODUCTION}

Soybean (Glycine max Merrill) is an important oil crop and rich in protein. The soybean is an excellent source of major nutrients including vitamins $A, B$ and $D$, rich in unsaturated fatty acids and minerals like $\mathrm{Ca}$ and $\mathrm{P}$ that can meet up different nutritional deficiencies (Rahman, 1982).It accounts for approximately $50 \%$ of the total production of oil crops in the world. Its' contains $42-$ $45 \%$ best quality protein and $20-22 \%$ edible oil (Mondal and Wahab, 2001). It has become the leading source of edible oils and fats, composing of about $20 \%$ of the world supply and more than any other single source of this essential food constituent (Singh et al.1989). Soybean plant has great importance for enriching soil. It improves the soil fertility and productivity. Soybean, like other legumes, has the ability to fix atmospheric $\mathrm{N}$ though root nodule bacteria (Bradyrhizobium japonicum) and thus enrich the soil fertility (Mahabal, 1986), It fixes about $270 \mathrm{~kg} \mathrm{~N} \mathrm{ha}^{-1}$ compared to 58 to $157 \mathrm{~kg} \mathrm{~N}^{-1}$ by other pulses (Hoque, 1978). This can compensate around $80-90 \%$ demand for nitrogen by the crops.

Soybean is being cultivated in Bangladesh as a minor crop and a little attention has been given on the improvement of its yield potentiality. Moreover, the yield of soybean is low in Bangladesh as

\footnotetext{
* Corresponding author: Scientific Officer, Entomology Division, BARI, Gazipur 1701. E-mail: mkafil77@yahoo.com

(C) 2006 School of Agriculture and Rural Development, Bangladesh Open University, All rights reserved.
} 
compared to other oil producing countries. (Nasreen and Bhuiyan, 1997). The yield is greatly influenced by its biomass production. Time of planting is very important for the development of canopy structure as well as biomass production. However, information on planting time in relation to canopy structure and biomass production is scanty in Bangladesh. An effort was made to investigate the effect of date of planting on (i) morphological features; (ii) root \& shoot biomass production and their relationships with total dry matter (TDM) in four soybean genotypes under Mymensingh condition.

\section{MATERIALS AND METHODS}

The experiment was carried out at the field laboratory of the Department of Crop Botany, Bangladesh Agricultural University, Mymensingh, during the period from November 2003 to May 2004 in the medium highland of Old Brahmaputra Floodplain (AEZ 9). The soil was silty loam and acidic in nature (pH 6.8). Four genotypes of soyabean viz. GPB-1, GPB-2, AGS-332 and AGS-1135 were used in the experiment with two different planting dates being 13 November \&13 December of 2003. The experiment was laid out in Randomized Complete Block Design with three replications. The plot size was $2 \mathrm{~m}^{2}$ and the spacing was $30 \mathrm{~cm} \times 5 \mathrm{~cm}$. Five seeds were placed $5 \mathrm{~cm}$ depth in each hole and two seedlings were removed keeping the healthy one after 15-20 days. The soil was treated with insecticide, Sevin @ $4.2 \mathrm{~kg} \mathrm{ha}^{-1}$ to protect the young seedlings from the attack of cutworm. Fertilizers were applied @ cowdung $6.0 \mathrm{t} \mathrm{ha}^{-1}$, Urea $20 \mathrm{~kg} \mathrm{ha}^{-1}$, TSP $25 \mathrm{~kg} \mathrm{ha}^{-}$ ${ }^{1}$ and MP $25 \mathrm{~kg} \mathrm{ha}^{-1}$. Intercultural operations were done as and when required. The recorded data were compiled and analyzed with computer package MSTAT C.

\section{RESULTS AND DISCUSSION}

\section{Effect of planting time and genotype on canopy structure}

Time of planting significantly influenced the different components of canopy structure such as plant height, stem base diameter, number of branches plant $^{-1}$ and number of leaves plant $^{-1}$ (Table 1). Plant height and stem base diameter were greater in December planting while number of branches plant $^{-1}$ and number of leaves plant ${ }^{-1}$ were greater in November planting. Canopy structures were significantly affected by the genotypes. Greater plant height was significant in the genotype GPB- 2 $(63.2 \mathrm{~cm})$ whereas other genotypes were statistically identical to each other varying from 44.8 to $47.5 \mathrm{~cm}$. Thicker stem base diameter was found in AGS-332 $(3.9 \mathrm{~mm})$ which was statistically similar to AGS-11-35 (3.7 mm). Number of branches plant ${ }^{-1}$ was higher in GPB-2 (3.6) compared to GPB-1, and AGS-332 and AGS-11-35. Highest number of leaves plant ${ }^{-1}$ was found in GPB-2 (15.0) followed by GPB-1, AGS-332 and AGS-11-35. Interaction between planting time and genotypes resulted increased plant height in December planting compared to November planting in all genotypes (Table 2). It might be due to receiving increased temperature by the genotypes of December planting during its life time. Schench and Smith (1982) found a little affect of soil temperature on plant height of soybean. Among the genotypes, the highest plant height was recorded from GPB-2 $(66.9 \mathrm{~cm})$ which was statistically similar to GPB-1 $(61.1 \mathrm{~cm})$. Number of branches plant- ${ }^{1}$ followed a composite trend. In GPB-2 number of branch/plant decreased in December planting compared to November planting. In other genotypes, the number of branches plant ${ }^{1}$ was increased in December planting compared to November planting with being greater increase in GPB-1 than in the AGS-332 and AGS-11-35. Stem base diameter followed a trend similar to pattern of number of branches plant $^{-1}$ with greater degree of increased in stem base diameter in GPB-1 than in the others. In contrast at maturity stage, the number of leaves plant ${ }^{-1}$ decreased in December planting compared to November planting with being greater decreased in GPB-2 than in the AGS-11-35, GPB-1 and AGS-332. 
Effect of planting time on canopy structure and biomass production in some soybean genotypes

Table 1. Effect of planting time and genotype on canopy structure at maturity in Soybean

\begin{tabular}{|c|c|c|c|c|}
\hline Treatment & $\begin{array}{c}\text { Plant } \\
\text { height }(\mathrm{cm}) \\
\end{array}$ & $\begin{array}{c}\text { Stem base } \\
\text { diameter }(\mathrm{mm})\end{array}$ & $\begin{array}{c}\text { Branch plant }^{-1} \\
\text { (no.) }\end{array}$ & $\begin{array}{c}\text { Leaf plant }^{-1} \\
\text { (no.) }\end{array}$ \\
\hline \multicolumn{5}{|l|}{ Planting time } \\
\hline November & $41.3 \mathrm{~b}$ & $3.5 \mathrm{~b}$ & $1.7 \mathrm{a}$ & $13.2 \mathrm{a}$ \\
\hline December & $59.6 \mathrm{a}$ & $3.7 \mathrm{a}$ & $1.6 \mathrm{~b}$ & $9.4 \mathrm{~b}$ \\
\hline \multicolumn{5}{|l|}{ Genotypes } \\
\hline GPB-1 & $47.5 \mathrm{~b}$ & $3.4 \mathrm{~b}$ & $1.6 \mathrm{~b}$ & $13.2 \mathrm{~b}$ \\
\hline GPB-2 & $63.2 \mathrm{a}$ & $3.5 \mathrm{~b}$ & $2.6 \mathrm{a}$ & $15.0 \mathrm{a}$ \\
\hline AGS-332 & $46.4 \mathrm{~b}$ & $3.9 \mathrm{a}$ & $1.1 \mathrm{c}$ & $10.1 \mathrm{c}$ \\
\hline AGS-11-35 & $44.8 \mathrm{~b}$ & $3.7 \mathrm{ab}$ & $1.2 \mathrm{C}$ & $6.9 \mathrm{~d}$ \\
\hline
\end{tabular}

Under either time of planting or genotype separates, figures with uncommon letter(s) are significantly $(\mathrm{P} \leq 0.05)$ different by DMRT.

Table 2. Interaction effect of planting time and genotype on canopy structure at maturity stage in soybean

\begin{tabular}{clcccc}
\hline $\begin{array}{c}\text { Time of } \\
\text { planting }\end{array}$ & Genotypes & Plant height $(\mathrm{cm})$ & $\begin{array}{c}\text { Stem base } \\
\text { diameter }(\mathrm{mm})\end{array}$ & $\begin{array}{c}\text { Branch plant }^{-1} \\
\text { (no.) }\end{array}$ & $\begin{array}{c}\text { Leaf plant }^{-1} \\
\text { (no.) }\end{array}$ \\
\hline \hline \multirow{5}{*}{ November } & GPB-1 & $33.9 \mathrm{~d}$ & $3.1 \mathrm{c}$ & $1.3 \mathrm{c}$ & $14.8 \mathrm{~b}$ \\
& GPB-2 & $59.6 \mathrm{~b}$ & $3.6 \mathrm{ab}$ & $3.3 \mathrm{a}$ & $19.1 \mathrm{a}$ \\
& AGS-332 & $34.7 \mathrm{~d}$ & $3.7 \mathrm{ab}$ & $1.0 \mathrm{~d}$ & $10.9 \mathrm{~cd}$ \\
& AGS-11-35 & $37.0 \mathrm{~d}$ & $3.6 \mathrm{ab}$ & $1.1 \mathrm{~cd}$ & $8.3 \mathrm{e}$ \\
\hline \multirow{5}{*}{ December } & GPB-1 & $61.1 \mathrm{ab}$ & $3.7 \mathrm{ab}$ & $1.9 \mathrm{~b}$ & $11.6 \mathrm{c}$ \\
& GPB-2 & $66.9 \mathrm{a}$ & $3.3 \mathrm{bc}$ & $1.8 \mathrm{~b})$ & $11.0 \mathrm{~cd}$ \\
& AGS-332 & $58.0 \mathrm{bc}$ & $4.0 \mathrm{a}$ & $1.3 \mathrm{c}$ & $9.4 \mathrm{de}$ \\
& AGS-11-35 & $52.5 \mathrm{c}$ & $3.8 \mathrm{a}$ & $1.3 \mathrm{c}$ & $5.5 \mathrm{f}$ \\
\hline
\end{tabular}

In a column, figures with uncommon letter(s) are significantly $(\mathrm{P} \leq 0.05)$ different by DMRT.

\section{Effect of planting time and genotype on biomass production}

Effect of planting time on leaf, shoot, root and dry mass was significant $(p<0.05)($ Table 3$)$. Higher leaf dry weight plant ${ }^{-1}$ was obtained in November planting (4.1g) than in December planting (3.6g). In contrast, shoot and root and, total dry mass was greater in November planting than in the December (Table 3). The effect of genotype on biomass production and harvest index was significant. Higher leaf dry weight plant ${ }^{-1}$ was observed in AGS-332 (4.2 g) than in the GPB-1 and GPB-2(3.7g). In contrast the shoot dry weight plant ${ }^{-1}$ was greater in GPB-2 and GPB-1(average of $25.25 \mathrm{~g}$ ) and than in other two (average of $17.6 \mathrm{~g}$ ). Root dry weight plant ${ }^{-1}$ was greater in AGS-11$35(0.8 \mathrm{~g})$ than other genotypes. Total dry matter (TDM) was greater in GPB-1 and GPB-2 (average of $25 \mathrm{~g}$ ) than AGS-332(19.9g) and AGS-11-35(16.7g) (Table 3).

The Interaction effect on leaf dry weight, shoot and root dry weight and total dry matter were significant (Table 4). Leaf dry weight plant ${ }^{-1}$ increased in GPB-1 and GPB-2 in December planting compared to November planting. In other genotypes leaf dry weight plant $^{-1}$ was decreased in December planting compared to November planting. Root dry weight plant ${ }^{-1}$ was increased more in GPB-1 than in GPB-2 in December planting compared to November planting whereas root dry weight decreased in other two genotypes in the late planting than in the earlier one. Shoot dry weight and total dry mass (TDM) followed a similar pattern. The shoot dry weight and TDM increased in GPB-1 in December planting compared to November one. In the other genotypes, in contrast, GPB-2, AGS-332 and AGS-11-35, the shoot dry weight and TDM decreased in December planting compared to November one. Early planting compared to late produced greater number of leaves and branches plant ${ }^{-1}$ and hence may have produced greater total dry mass (TDM). The present result is similar to the findings of Settimi and Board (1988) and Kang Youngkil et al. (1998) who reported that plant height, branch production, and diameter and node number of main stem decreased with delayed planting. Such reduction of the canopy components is responsible for smaller biomass production by reducing the length of vegetative period (Board et al., 1986). Generally the two AGSs genotypes had smaller TDM than in the other two genotypes (Table 3) and this variation may be due to fewer leaf and branch development in the former than in the latter genotypes (Table 1). That is total dry mass depends on size and function of canopy structures 
(Gan et al., 2002). Genetic differences for canopy structure and biomass yield were also observed by Parvez et al., (1989). Further significant and positive correlation of TDM with number of leaves plant $^{-1}(r=0.75, p<0.01)$ and shoot dry weight $(r=0.96, p<0.01)$ indicate that biomass can be improved by increases leaf and shoot development (Fig.1).

Results reveal that November planting may be better for GPB-2 but December for GPB-1 for high biomass production. However, trials are attempted for confirmation of the results.

Table 3. Effect of planting time and genotype on biomass production in soybean Genotypes

\begin{tabular}{ccccc}
\hline Treatment & $\begin{array}{c}\text { Leaf dry wt. } \\
\text { plant }^{-1}(\mathrm{~g})\end{array}$ & $\begin{array}{c}\text { Shoot dry wt. } \\
\text { plant }^{-1}(\mathrm{~g})\end{array}$ & $\begin{array}{c}\text {R}^{\text {Root dry wt plant }}{ }^{-1} \\
(\mathrm{~g})\end{array}$ & $\begin{array}{c}\text { Total DM plant }^{-1} \\
(\mathrm{~g})\end{array}$ \\
\hline \hline Planting time & & & & $25.4 \mathrm{a}$ \\
\hline November & $4.1 \mathrm{a}$ & $25.5 \mathrm{a}$ & $0.7 \mathrm{a}$ & $17.9 \mathrm{~b}$ \\
December & $3.6 \mathrm{~b}$ & $17.3 \mathrm{~b}$ & & $24.6 \mathrm{a}$ \\
\hline Genotypes & & & $0.5 \mathrm{c}$ & $25.4 \mathrm{a}$ \\
GPB-1 & $3.7 \mathrm{~b}$ & $24.1 \mathrm{a}$ & $0.7 \mathrm{~b}$ & $19.9 \mathrm{~b}$ \\
AGB-2 & $3.7 \mathrm{~b}$ & $26.4 \mathrm{a}$ & $0.7 \mathrm{~b}$ & $16.7 \mathrm{c}$ \\
\hline AGS-11-35 & $4.2 \mathrm{a}$ & $19.3 \mathrm{~b}$ & $0.8 \mathrm{a}$ & $\mathrm{b}$ \\
\hline
\end{tabular}

Under either time of planting or genotype, figures with uncommon letter(s) are significantly $(\mathrm{P} \leq 0.05)$ different by DMRT.

Table 4. Interaction effect of planting time and genotype on biomass and harvest index (HI) at maturity in soybean

\begin{tabular}{|c|c|c|c|c|c|}
\hline $\begin{array}{l}\text { Time of } \\
\text { planting }\end{array}$ & Genotype & $\begin{array}{l}\text { Leaf dry wt. } \\
\text { plant }^{-1}(\mathrm{~g})\end{array}$ & $\begin{array}{l}\text { Shoot dry wt. } \\
\text { plant }^{-1} \text { (g) }\end{array}$ & $\begin{array}{l}\text { Root dry wt } \\
\text { plant }^{-1}(\mathrm{~g})\end{array}$ & $\begin{array}{l}\text { Total DM } \\
\text { plant }^{-1}(\mathrm{~g})\end{array}$ \\
\hline \multirow{4}{*}{ November } & GPB-1 & $3.6 \mathrm{c}$ & $22.1 \mathrm{bc}$ & $0.4 \mathrm{~d}$ & $22.5 \mathrm{c}$ \\
\hline & GPB-2 & $3.6 \mathrm{c}$ & $37.4 \mathrm{a}$ & $0.6 \mathrm{c}$ & $34.6 \mathrm{a}$ \\
\hline & AGS-332 & $5.1 \mathrm{a}$ & $24.7 \mathrm{~b}$ & $0.8 d$ & $25.5 \mathrm{bd}$ \\
\hline & AGS-11-35 & $4.1 \mathrm{~b}$ & $17.9 \mathrm{~cd}$ & $0.9 \mathrm{a}$ & $18.9 \mathrm{~d}$ \\
\hline \multirow{4}{*}{ December } & GPB-1 & $3.7 \mathrm{bc}$ & $26.0 \mathrm{~b}$ & $0.6 \mathrm{c}$ & $26.7 \mathrm{~b}$ \\
\hline & GPB-2 & $3.7 \mathrm{bc}$ & $15.3 d$ & $0.7 \mathrm{~b}$ & 16.0de \\
\hline & AGS-332 & $3.3 \mathrm{c}$ & $13.9 \mathrm{~d}$ & $0.6 \mathrm{c}$ & $14.5 \mathrm{e}$ \\
\hline & AGS-11-35 & $3.7 \mathrm{bc}$ & $13.8 \mathrm{~d}$ & $0.7 \mathrm{~b}$ & $14.5 \mathrm{e}$ \\
\hline
\end{tabular}

In a column, figures with uncommon letter(s) are significantly $(P \leq 0.05)$ different by DMRT.
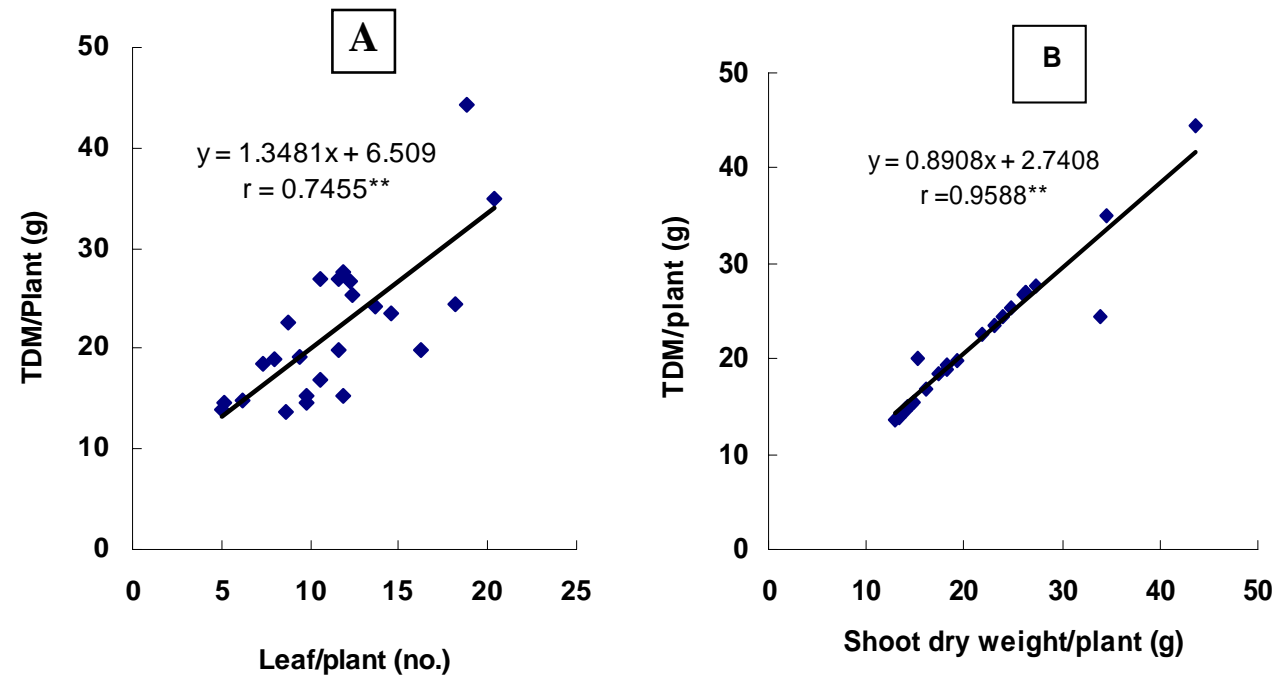

Fig. 1. Relationship of total dry mass (TDM) with the number of leaf/plant (A) and shoot dry weight $(B)$ in four soybean genotypes. $N=24$ (4 var. $\times 2$ planting $\times 3$ replications). 


\section{LITERATURE CITED}

Board, J. E. and Settime, J. R. 1986. Photoperiod effect before and after flowering on branch development in determinate soybean. Agron. J. 78(6), 995-1002.

Gan, Y., Stulen, I., Kenlen, H.Van, Kuiper, P.J.C. and Van Keulen, H. 2002. Physiological response of soybean genotypes to plant density. Field Crops Research. 74(2-3),231-241.

Gareia, A. 1994. Tropical soybean improvement and production. FAO. p. 115-121.

Hoque, M. S 1978. Present availability of nitrogen from organic waste and biological source. Paper presented at the seminar on nitrogen in crop production December - January, 1977-1978, Dhaka.

Mahabal, R. 1986. High yielding varieties of crops. All Indian co-coodinated Barley Improvement project, IARI Regional station Kamal (Haryana),p.641.

Mondal, M. R. I. and Wahhab, M. A. 2001. Production technology of oilseed crops. Oil seed research centre, Bangladesh Agricultural Research Institute, Joydebpur, Gazipur-1701. p. 57.

Nasreen, S. and Bhuiyan, M.A.H. 1997. Response of soybean to phosphorus and sulphur fertilization. Bangladesh Journal of Agricultural science. 24(1), 111-116.

Parvez, A. Q., Gardner, F. F. and Boote, K. J. 1989. Determinate and indeterminate type soybean cultivar responses to pattern, density and planting date. Crop Sci. 29(1), 150-157.

Rahman, L. 1982. Cultivation of soybean and its, use. City press. Dhaka pp. 5-7.

Scench, N. C. and Smith, G. S. 1982. Response of six species of vesicular-arbuscular mycorrhizal fungi and their effects on soybean at four soil temperature. New Phytologist. 92(2), 193-201.

Settimi, J. R. and Board, J. E. 1988. Photoperiod and planting date effects on the spatial distribution of branch development in soybean. Crop Sci. 28(2), 259-263.

Singh, S. R., Rachie, K. O. and Dashiell, K. E. 1989. Soybean for the tropics: Research, production and utilization, p. 15. 